\title{
PEMBELAJARAN MENDENGARKAN CERITA ANAK BERBASIS PENDIDIKAN KARAKTER UNTUK MENGEMBANGKAN PRIBADI SISWA
}

\author{
Oleh: \\ Elfy Rachmanita \\ Email: elfyrachmanita@yahoo.com \\ Mahasiswa Magister Pendidikan Bahasa dan Sastra Indonesia \\ Universitas Muhammadiyah Malang
}

\begin{abstract}
Abstrak: Cerita merupakan salah satu wujud budaya yang berupa hasil karya masyarakat Indonesia. Penyebaran cerita pada umumnya dilakukan secara lisan. Melalui kelisanan tersebut, penyimak cerita dapat memahamai kejadian, sejarah, dan asal usul sebuah tempat. Cerita yang ditujukan khusus untuk anak-anak sering disebut cerita anak. Cerita anak mengandung pesan yang bermanfaat bagi perkembangan moral anak. Cerita anak dapat dijadikan media pembelajaran yang berpotensi besar mengembangkan karakter siswa, khususnya siswa SMP.
\end{abstract}

Kata Kunci: pembelajaran mendengarkan, cerita anak, pendidikan karakter, pribadi siswa.

\section{Pendahuluan}

Kemajuan suatu bangsa dan negara sangat ditentukan oleh sumber daya manusia (SDM). Mutu SDM tidak hanya dilihat dari kualitas ilmu pengetahuannya saja, tetapi dari karakter serta perilakunya. Karakter serta perilaku individu harus dipupuk mulai dari dini khususnya di lingkungan sekolah. Guru harus menjadi fasilitator serta motivator untuk perkembangan karakter siswa. Hal tersebut dapat dilakukan dengan salah satunya dengan cara mengenalkan dan menyajikan bacaan yang sesuai dengan periode perkembangan siswa. Pemerintah sudah mencanangkan 18 nilai-nilai dalam pengembangan pendidikan budaya dan karakter bangsa. Mulai tahun ajaran 2011, seluruh tingkat pendidikan di Indonesia harus menyisipkan pendidikan berkarakter tersebut dalam proses pendidikannya

Buchori (2007) mengatakan bahwa pengembangan karakter seharusnya membawa anak ke pengenalan nilai secara kognitif, penghayatan nilai secara afektif, akhirnya ke pengamalan nilai secara nyata. Salah satu cara untuk mengenalkan nilainilai tersebut di sekolah adalah dengan pembelajaran mendengarkan cerita anak. Perkembangan anak akan berjalan wajar dan sesuai dengan periodenya bila disajikan bahan bacaan yang sesuai pula. Bacaan yang akan disajikan bagi anak harus mengandung tema yang mendidik, tidak berbelit-belit, menggunakan setting yang ada di sekitar mereka atau ada di dunia mereka, tokoh dan penokohan mengandung 
teladan yang baik, gaya bahasanya mudah dipahami tetapi mampu mengembangkan bahasa anak, dan imajinasi masih dalam jangkauan anak.

Guru dapat menjadikan cerita anak sebagai pilihan pembelajaran berbasis pendidikan karakter untuk menanamkan karakter yang sesuai dengan nila-nilai karakter yang sudah dikembangkan oleh Diknas. Selain untuk menanamkan nilainilai tersebut, cerita anak juga dapat dijadikan sebagai alat yang untuk mengembangkan imajinasi serta kreativitas siswa.

Berdasarkan kondisi yang dikemukakan di atas, pembahasan masalah pada artikel ini akan menyajikan uraian tentang: (1) hakikat cerita anak, (2) hakikat pendidikan karakter, (3) manfaat pembelajaran cerita anak, (4) pembelajaran mendengarkan cerita anak, serta (5) hubungan pembelajaran mendengarkan cerita anak dengan pendidikan karakter.

\section{Cerita Anak}

Mustakhim (2005: 12) menyatakan bahwa "cerita merupakan gambaran tentang kejadian suatu tempat, kehidupan binatang sebagai perlambang kehidupan manusia, kehidupan manusia dalam masyarakat, dan cerita tentang mite yang hidup dalam masyarakat kapan dan dimana cerita itu terjadi”. Cerita sudah sejak dulu ada disampaikan secara lisan, kemudian berkembang terus menjadi bahan cetakan berupa buku, kaset, video, dan film atau cinema. Cerita berada pada posisi pertama dalam mendidik etika kepada anak. Mereka cenderung menyukai dan menikmatinya, baik dari segi ide, imajinasi maupun peristiwa-peristiwanya. Jika hal ini dapat dilakukan dengan baik, cerita akan menjadi bagian dari seni yang disukai anak-anak, bahkan orang dewasa.

Cerita anak adalah kisah nyata atau rekaan yang berbentuk prosa yang bertujuan menghibur pembacanya yang dikhususkan untuk anak-anak dan termasuk ke dalam sastra anak. Sesuai dengan sasaran pembacanya, sastra anak dituntut untuk dikemas dalam bentuk yang berbeda dari sastra orang dewasa hingga dapat diterima anak dan dipahami mereka dengan baik. Puryanto (2008:2) menjelaskan bahwa "sastra anak merupakan pembayangan atau pelukisan kehidupan anak yang imajinatif ke dalam bentuk struktur bahasa anak. Sastra anak merupakan sastra yang ditujukan untuk anak, bukan sastra tentang anak. Sastra tentang anak bisa saja isinya tidak sesuai untuk anak-anak, tetapi sastra untuk anak sudah tentu sengaja dan disesuaikan untuk anak-anak selaku pembacanya".

Cerita anak dapat ditemukan di berbagai media seperti buku anak-anak, majalah, koran, tabloid, bahkan internet. Tarigan (1995: 5) menyatakan bahwa "buku anak-anak biasanya mencerminkan masalah-masalah masa kini. Hal-hal yang dibaca oleh anak-anak dalam koran, yang ditontonnya dilayar televisi dan di bioskop, cenderung pada masalah-masalah masa kini. Bahkan yang dialaminya di rumah pun adalah situasi masa kini”.

Cerita anak seharusnya dapat dipahami oleh anak-anak dan berisi tentang dunia yang akrab dengan anak-anak. Seperti pada jenis karya sastra umumnya, cerita anak juga berfungsi sebagai media pendidikan dan hiburan, membentuk kepribadian anak, serta menuntun 
kecerdasan emosi anak. Pendidikan dalam cerita anak memuat amanat tentang moral, pembentukan kepribadian anak, mengembangkan imajinasi dan kreativitas, serta memberi pengetahuan keterampilan praktis bagi anak. Sebagai hiburan, cerita anak berfungsi membuat anak merasa bahagia atau senang membaca, senang dan gembira mendengarkan cerita ketika dibacakan dan mendapatkan kenikmatana. atau kepuasan batin sehingga menuntun kecerdasan emosinya.

Cerita anak merupakan kisah sederhana yang ditulis untuk anak, berbicara mengenai kehidupan anak dan sekeliling yang mempengaruhi anak, di dalamnya mencerminkan liku-likub. kehidupan yang dapat dipahami oleh anak, melukiskan perasaan anak, dan menggambarkan pemikiran-pemikiran anak. Cerita anak berbentuk prosa yang menceritakan suatu peristiwa yang singkatc. dan padat jumlah pengembangan pelaku terbatas, keseluruhan cerita memberikan kesan tunggal serta mencerminkan perasaan pengalaman anak-anak, dan ditujukan bagi anak. Cerita anak sangat berarti bagi anakanak. Sebagai bacaan penghibur, ada sisi lain yang bermanfaat baginya yaitu sebagai pengasah rasa empati dalam jiwanya. Dalam hal ini cerita anak dapat digunakan untuk mendapatkan pengalaman berharga yang dapat menolong membentuk jiwa anak-anak supaya kelak menjadi anak yang baik.

Secara singkat, Puryanto (2008: 7) menjelaskan "ciri dan syarat cerita anak adalah mengandung tema yang mendidik, alurnya lurus dan tidak berbelit-belit, menggunakan setting yang ada di sekitar atau ada di dunia anak, tokoh dan penokohan mengandung peneladanan yang baik, gaya bahasanya mudah dipahami tapi mampu mengembangkan bahasa anak, sudut pandang orang yang tepat, dan imajinasi masih dalam jangkauan anak".

Menurut Sarumpaet (Dalam Santoso, 2003:8.4), ada 3 ciri cerita anak yang membedakannya dengan cerita dewasa, ciri tersebut adalah:

Unsur pantangan, yaitu unsur yang yang secara khusus berhubungan dengan tema dan amanat. Artinya, cerita anak pantang atau menghindari masalah-masalah yang menyangkut tentang seks, cinta yang erotis, dendam yang menimbulkan kebencian atau hal-hal yang bersifat negatif.

Penyajian dengan gaya secara langsung, artinya tokoh yang diperankan sifatnya hitam putih. Maksudnya adalah setiap tokoh yang berperan hanya mempunyai satu sifat utama, yaitu baik atau jahat.

Fungsi terapan adalah sajian cerita harus bersifat menambah pengetahuan yang bermanfaat.

\section{Pendidikan Karakter}

Koesoema dalam buku pendidikan karakter (2007:3) menjelaskan bahwa "karakter lebih bersifat subjektif sebab berkaitan dengan struktur antropologis dan tindakannya dalam memaknai kebebasannya, sehingga ia mengukuhkan keunikannya berhadapan dengan orang lain. Sementara pendidikan senantiasa berkaitan dengan dimensi sosialitas manusia". Oleh karena itu, pendidikan karakter merupakan keseluruhan dinamika relasional antarpribadi dengan berbagai macam dimensi, baik dari dalam maupun dari luar dirinya, agar pribadi itu semakin dapat menghayati kebebasannya, sehingga ia 
makin dapat bertanggungjawab atas pertumbuhan dirinya sendiri sebagai pribadi dan perkembangan orang lain dalam hidup mereka. Secara singkat, pendidikan karakter bisa diartikan sebagai sebuah bantuan sosial agar individu itu dapat bertumbuh dalam menghayati kebebasannya dalam hidup bersama dengan orang lain dalam kehidupan mereka.

Pendidikan karakter juga merupakan sistem penanaman nilai-nilai karakter kepada siswa yang meliputi komponen pengetahuan, kesadaran, kemauan, dan tindakan untuk melaksanakan nilai-nilai, baik terhadap agama, diri sendiri, lingkungan, maupun negara sehingga menjadi manusia yang berbudi. Dalam pendidikan karakter di sekolah, semua komponen harus dilibatkan, termasuk komponen-komponen pendidikan itu sendiri, yaitu isi kurikulum, proses pembelajaran dan penilaian, pengelolaan sekolah, pelaksanaan aktivitas, pemberdayaan sarana prasarana, pembiayaan, dan kebiasaan seluruh warga dan lingkungan sekolah.

Pendidikan karakter dapat diintegrasikan dalam pembelajaran pada setiap mata pelajaran. Materi pembelajaran yang berkaitan dengan norma atau nilainilai pada setiap mata pelajaran perlu dikembangkan dan dikaitkan dengan konteks kehidupan sehari-hari. Dengan demikian pembelajaran nilai-nilai karakter tidak hanya pada tataran kognitif, tetapi menyentuh pada internalisasi dan pengamalan nyata dalam kehidupan peserta didik sehari-hari di masyarakat.

Pendidikan karakter bertujuan untuk meningkatkan mutu penyelenggaraan dan hasil pendidikan di sekolah yang mengarah pada pencapaian pembentukan karakter dan akhlak mulia peserta didik secara utuh, terpadu, dan seimbang, sesuai standar kompetensi lulusan. Melalui pendidikan karakter diharapkan peserta didik mampu secara mandiri meningkatkan dan menggunakan pengetahuannya, mengkaji dan menginternalisasi serta mempersonalisasi nilai-nilai karakter dan akhlak mulia sehingga terwujud dalam perilaku sehari-hari. Melalui program ini diharapkan setiap lulusan memiliki keimanan dan ketaqwaan kepada Tuhan Yang Maha Esa, berakhlak mulia, berkarakter mulia, kompetensi akademik yang utuh dan terpadu, sekaligus memiliki kepribadian yang baik sesuai norma-norma dan budaya Indonesia. Pada tataran yang lebih luas, pendidikan karakter nantinya diharapkan menjadi budaya sekolah.

Foerster (dalam Soedijarto, 2007:243) menjelaskan bahwa ada empat ciri-ciri dasar dalam pendidikan karakter, yaitu sebagai berikut.

a. Keteraturan interior di mana setiap tindakan diukur berdasar hirarki nilai.Nilai menjadi pedoman normatif setiap tindakan.

b. Koherensi yang member kerberanian, membuat seorang teguh pada prinsip, tidak mudah terombang-ambing pada situasi baru atau takut resiko. Koherernsi merupakan dasar yang membangun rasa percaya satu sama lain. Tidak adanya koherensi akan meruntuhkan kredibilitas seseorang.

c. Otonomi. Seseorang menginternalisasikan aturan dari luar sampai menjadi nilai-nilai bagi pribadi. Otonomi dapat dilihat lewat 
penilaian atas keputusan pribadi tanpa terpengaruh atau desakan pihak lain.

d. Keteguhan dan kesetiaan.

Keteguhan merupakan daya tahan seseorang guna menginginkan apa yang dipandang baik dan kesetiaan merupakan dasar bagi penghormatan atas komitmen yang dipilih.

Pendidikan karakter di sekolah sangat terkait dengan manajemen atau pengelolaan sekolah. Pengelolaan yang dimaksud adalah bagaimana pendidikan karakter direncanakan, dilaksanakan, dan dikendalikan dalam kegiatan-kegiatan pendidikan di sekolah secara memadai. Pengelolaan tersebut antara lain meliputi, nilai-nilai yang perlu ditanamkan, muatan kurikulum, pembelajaran, penilaian, pendidik dan tenaga kependidikan, dan komponen terkait lainnya. Dengan demikian manajemen sekolah merupakan salah satu media yang efektif dalam pendidikan karakter di sekolah. Pada tataran sekolah, kriteria pencapaian pendidikan karakter adalah terbentuknya budaya sekolah. Budaya sekolah yang dimaksud yaitu perilaku, tradisi, kebiasaan keseharian, dan simbol-simbol yang dipraktikkan oleh semua warga sekolah dan masyarakat sekitar sekolah.

Pendidikan karakter bersifat luas dan mencangkup berbagai aspek, Latif (2009:82-83) menguraikannya menjadi 3 aspek, yaitu:

a. Pendidikan moral menitikberatkan dimensi etis dari individu dan masyarakat serta mememriksa bagaimana standar kebenaran dan kesalahan yang dikembangkan. b. Pendidikan kewargaan (civic education) memberikan kesempatan bagi keterlibatan aktif dalam prosesproses demokratis yang berlangsung di sekolah dan komunitas. Karakter seorang individu harus dikembangkan mulai dini agar mereka paham akan aspek-aspek yang ada dalam kehidupan.

c. Pengembangan karakter adalah suatu pendekatan holistik yang menghubungkan dimensi moral pendidikan dengan ranah sosial dan sipil dari kehidupan siswa. Sikap dan nilai dasar dari masyarakat diidentifikasi dan diteguhkan di sekolah dan komunitas.pendidikan bersifat sarat nilai, karena masyarakat menentukan apa-apa yang akan dan tidak akan diteladani.

Pendidikan karakter pada intinya bertujuan membentuk bangsa yang tangguh,kompetitif, berakhlak mulia, bermoral, bertoleran, bergotong royong, berjiwa patriotik,berkembang dinamis, berorientasi ilmu pengetahuan dan teknologi yang semuanya dijiwaioleh iman dan takwa kepada Tuhan yang Maha Esa berdasarkan Pancasila. Utomo (2011:2) menjelaskan fungsi pendidikan karakter sebagai berikut:(1) mengembangkan potensi dasar agar berhati baik,berpikiran baik, dan berperilaku baik; (2) memperkuat dan membangun perilaku bangsa yang multikultur; (3) meningkatkan peradaban bangsa yang kompetitif dalam pergaulan dunia.Pendidikan karakter dilakukan melalui berbagai media yang mencakup keluarga,satuan pendidikan, masyarakat sipil, masyarakat politik, pemerintah, dunia usaha, dan mediamassa. 
Lickona (dalam Soedijarto, 2007:245) menekankan "pentingnya tiga komponen karakter yang baik (components of good character) yaitu moral knowing (pengetahuan tentang moral), moral feeling (perasaan tentang moral), dan moral action (perbuatan bermoral). Hal ini diperlukan agar anak mampu memahami, merasakan, dan mengerjakan sekaligus nilai-nilai kebajikan". Anak yang diajarkan tentang pendidikan karakter diharapkan mampu memahami nilai-nilai yang disampaikan dalam pembelajaran, merasakan kebanaran serta kesalahan yang benar-benar terjadi dalam kehidupan serta mengamalkan dan mengintegrasikan nilai-nilai tersebut pada kehidupannya.

Dalam rangka lebih memperkuat pelaksanaan pendidikan karakter, telah teridentifikasi18 nilai yang bersumber dari agama, Pancasila, budaya, dan tujuan pendidikan nasional, yaitu:(1) Religius, (2) Jujur, (3) Toleransi, (4) Disiplin, (5) Kerja keras, (6) Kreatif, (7) Mandiri, (8)Demokratis, (9) Rasa Ingin Tahu, (10) Semangat Kebangsaan, (11) Cinta Tanah Air, (12)Menghargai Prestasi, Bersahabat/Komunikatif, (14) Cinta Damai, (15) Gemar Membaca,(16) Peduli Lingkungan, (17) Peduli Sosial, \& (18) Tanggung Jawab (Utomo, 2011:3).

Nilai-nilai tersebut seharusnya dimiliki oleh seorang anak dan dirapkan anak tersebut mampu menerapkannya dalam kehidupan nyata. Penjabaran nilainilai tersebut yaitu: pertama, religius merupakan sikap dan perilaku patuh dalam melaksanakan ajaran agama yang dianutnya, toleran terhadap pelaksanaan ibadah agama lain, dan hidup rukun dengan pemeluk agama lain. Nilai ini adalah nilai utama yang harus dimiliki oleh seseorang karena dengan nilai religius, diharapkan mereka menerapkan ajaran yang dianutnya di dalam kehidupan nyata.

Kedua, jujur adalah perilaku yang didasarkan pada upaya menjadikan dirinya sebagai orang yang selalu dapat dipercaya dalam perkataan, tindakan, dan pekerjaan. Ketiga, toleransi merupakan sikap dan tindakan yang menghargai perbedaan agama, suku, etnis, pendapat, sikap, dan tindakan orang lain yang berbeda dari dirinya.

Keempat, disiplin adalah tindakan yang menunjukkan perilaku tertib dan patuh pada berbagai ketentuan dan peraturan. Kelima, kerja keras adalah tindakan yang menunjukkan perilaku aktif untuk memenuhi keinginginan yang diinginkannya. Keenam, kreatif adalah berpikir dan melakukan sesuatu untuk menghasilkan cara atau hasil baru dari sesuatu yang telah dimiliki. Ketujuh, mandiri adalah sikap dan perilaku yang tidak mudah tergantung pada orang lain dalam menyelesaikan tugas-tugas. Kedelapan, demokratis marupakan cara berfikir, bersikap, dan bertindak yang menilai sama hak dan kewajiban dirinya dan orang lain. Kesembilan, rasa ingin tahu adalah rasa sikap dan tindakan yang selalu berupaya untuk mengetahui lebih mendalam dan meluas dari sesuatu yang dipelajarinya, dilihat, dan didengar.

Nilai selanjutnya adalah semangat kebangsaan dan cinta tanah air adalah cara berpikir, bertindak, dan berwawasan yang menempatkan kepentingan bangsa dan negara di atas kepentingan diri dan kelompoknya. Keduabelas, menghargai prestasi merupakan sikap dan tindakan yang 
mendorong dirinya untuk menghasilkan sesuatu yang berguna bagi masyarakat, dan mengakui, serta menghormati keberhasilan orang lain. Ketigabelas, bersahabat/komunikatif adalah sikap dan tindakan yang mendorong dirinya untuk menghasilkan sesuatu yang berguna bagi masyarakat, dan mengakui, serta menghormati keberhasilan orang lain.

Nilai yang tidak kalah pentingnya adalah cinta damai merupakan sikap dan tindakan yang mendorong dirinya untuk menghasilkan sesuatu yang berguna bagi masyarakat, dan mengakui, serta menghormati keberhasilan orang lain. Nilai lain adalah gemar membaca merupakan kebiasaan menyediakan waktu untuk membaca berbagai bacaan yang memberikan kebajikan bagi dirinya.

Peduli lingkungan juga merupakan nilai yang diharapkan ada pada setiap karakter anak. Peduli lingkungan adalah sikap dan tindakan yang selalu berupaya mencegah kerusakan pada lingkungan alam di sekitarnya, dan mengembangkan upayaupaya untuk memperbaiki kerusakan alam yang sudah terjadi. Selain itu, peduli sosial juga penting karena merupakan sikap dan tindakan yang selalu ingin memberi bantuan pada orang lain dan masyarakat yang membutuhkan. Yang terakhir adalah bertanggung jawab yang merupakan sikap dan perilaku seseorang untuk melaksanakan tugas dan kewajibannya, yang seharusnya dia lakukan, terhadap diri sendiri, masyarakat, lingkungan (alam, sosial dan budaya), negara dan Tuhan Yang Maha Esa

\section{Manfaat Pembelajaran Cerita Anak}

Cerita anak mencerminkan kebiasaankebiasaan anak sehari-hari dari tokoh yang ditampilkan. Kebiasaan anak ada yang baik dan ada yang kurang baik. Anak harus bisa membedakan, menafsirkan, dan memahami pesan yang ingin disampaikan oleh penulis. Di dalam cerita anak juga tergambar cara berpikir, cita-cita, harapan dari tokoh yang ada untuk dapat direalisasikan dalam kehidupan pembaca. Musfiroh (2005:95115), memandang manfaat cerita dari berbagai aspek, yaitu sebagai berikut.

a) Membantu Pembentukan Pribadi dan Moral

Cerita sangat efektif untuk mempengaruhi cara berpikir dan berperilaku anak. Anak yang sudah terbiasa menyimak cerita, dalam jiwa mereka akan tumbuh pribadi yang hangat serta memiliki kecerdasan interpersonal. Selain itu cerita juga dapat mendorong perkembangan moral mereka. Sebuah cerita biasanya mengandung contoh perilaku buruk maupun contoh perilaku baik. Contoh perilaku buruk dimaksudkan agar dapat dihindari dalam kehidupan sehari-hari. Contoh perilaku baik dimaksudkan agar dapat ditiru untuk diterapkan dalam kehidupan seharihari.

b) Menyalurkan Kebutuhan Imajinasi

Anak membutuhkan penyaluran imajinasi tentang berbagai hal yang selalu muncul dalam pikiran mereka. Pada saat menyimak cerita, imajinasi mereka mulai dirangsang. Mereka membayangkan apa yang terjadi dan tokoh yang terlibat dalam cerita tersebut. Imajinasi yang dibangun anak saat menyimak cerita memberikan pengarauh positif terhadap kemampuan mereka menyelesaikan masalah secara kreatif. 
c) Memacu Kemampuan Verbal

Selama menyimak cerita, anak dapat belajar bagaimana bunyi-bunyi yang bermakna diujarkan dengan benar, bagaimana katakata itu disusun secara logis dan mudah dipahami, bagaimana konteks dan koteks berfungsi dalam makna. Cerita dapat juga mendorong anak untuk senang bercerita atau berbicara. Mereka dapat berlatih berdialog, berdiskusi antarteman untuk menuangkan kembali gagasan yang disimaknya.

d) Merangsang Minat Baca

Membacakan cerita dapata menjadi contoh yang efektif untuk menstimulus anak untuk gemar membaca. Seorang anak biasanya suka meniru-niru perilaku orang dewasa. Dari kegiatan bercerita, anak secara tidak langsung memperoleh contoh orang yang gemar dan pintar membaca dari apa yang dilihatnya.

e) Membuka Cakrawala Pengetahuan

Manfaat cerita sebagai pengembang cakrawala pengetahuan tampak pada ceritacerita yang memiliki karakteristik budaya, seperti mengenal nama-nama tempat cerita, bahasa-bahasa yang digunakan dalam cerita atau ungkapan-ungkapan yang digunakan dalam cerita tersebut. Hal itu tentu akan menambah pengetahuan mereka tentang hal yang belum pernah mereka ketahui.

Cerita-cerita memang sangat bermanfaat bagi seseorang dalam kehidupan sehari-hari, terutama bagi anakanak karena cerita itu dapat mendidik pola pikir dan perkembangan emosi mereka. Bagi seorang guru atau pun orang tua yang akan memilihkan cerita bagi siswa dan anak mereka, haruslah dapat memilihkan cerita yang sesuai dengan usia mereka.
1. Pembelajaran mendengarkan cerita anak untuk mengembangkan pribadi siswa

Keterampilan mendengarkan tidak dapat dipisahkan dari keterampilan berbahasa yang lain, yaitu keterampilan berbicara, membaca, dan menulis. Keberhasilan seseorang anak dalam mendengarkan dapat diketahui dari bagaimana anak tersebut memahami dan menyampaikan informasi dari materi yang diperdengarkan secara lisan atau tertulis. Hal ini menunjukkan bahwa keterampilan mendengarkan cukup kompleks jika anak ingin menangkap makna yang sesungguhnya dari wacana yang mungkin tidak seutuhnya tersurat, sehingga anak harus berusaha mengungkapkan hal-hal yang tersirat.

Akhadiah

(1993:149)

mengemukakan bahwa "peranan mendengarkan sebagai berikut; (1) dasar berlajar berbahasa; (2) penunjang keterampilan berbicara, membaca, dan menulis; (3) pelancar komunikasi lisan; (4) penambah informasi atau pengetahuan". Oleh sebab itu, dalam pembelajaran mendengarkan di sekolah seorang guru harus mampu menjadi fasilitator serta motifator yang baik agar anak mampu memahami serta memperoleh hasil yang maksimal dalam mendengarkan sebuah wacana.

$\begin{array}{lcrr}\text { Salah } & \text { satu } & \text { pembelajaran } \\ \text { mendengarkan di } & \text { SMP } & \text { adalah } \\ \text { mendengarkan cerita anak } & \text { dengan } \\ \text { kompetensi dasar menemukan realitas } \\ \text { kehidupan anak yang terefleksi dalam buku } \\ \text { cerita anak baik asli maupun terjemahan. } \\ \text { Dari pembelajaran ini siswa diharapkan } \\ \text { mampu (1) menemukan 5 judul cerita anak }\end{array}$


yang menarik, (2) menemukan kebiasaan kehidupan sehari-hari anak dalam cerita anak yang dibaca, (3) menemukan cara berpikir anak dalam cerita anak yang dibaca, (4) menemukan sikap anak dalam cerita anak yang dibaca, (5) menemukan masalah anak dalam cerita anak yang dibaca, (6) menemukan cita-cita/harapan anak dalam cerita anak yang dibaca, (7) menunjukkan contoh realitas kehidupan anak yang terefleksi dalam cerita anak yang dibaca.

Pembelajaran ini dapat dimulai dengan guru memberikan apersepsi kepada siswa untuk mengetahui seberapa jauh pemahaman siswa terhadap materi yang akan disampaikan. Agar keaktifan siswa lebih menonjol guru sebaiknya memberikan pancingan pertnyaan kepada siswa. Setelah guru mengetahui seberapa tingkat pengetahuan siswa terhadap materi yang 2 . akan disampaikan, guru dapat memberikan model atau contoh cerita anak kepada siswa dan kembali melakukan apersepsi tentang ciri-ciri dan pehamaman isi sebuah wacana cerita anak tersebut.

Dari model yang disampaikan oleh guru siswa siswa secara individu ditugasi untuk membuat tabel yang berisi kebiasaan kehidupan sehari-hari anak, cara berpikir anak, sikap anak, masalah yang dihadapi anak, dan cita-cita/harapan anak yang nampak pada cerita anak yang dijadikan model oleh guru. Selanjutnya, siswa ditugasi untuk memberikan contoh realitas kehidupan yang nampak pada cerita anak tersebut.

Pembelajaran selanjutnya lebih ditekankan pada sikap kerjasama siswa dengan teman sebayanya, siswa akan diberi tugas secara berkelompok. Kelompok terdiri kurang lebih 4-5 siswa. Kelompok ditugasi untuk mencari 5 judul cerita anak dan memilih satu yang dianggap paling menarik atas kesepakatan kelompok. Cerita anak tersebut lalu dianalisis oleh kelompok seperti pada model yang diberikan oleh gur pada awal pembelajaran. Akan tetapi, pada tugas kelompok ini siswa juga ditugasi untuk memberikan contoh kongkrit berupa berita, gambar atau foto tentang hal-hal yang mereka analisis tesebut.

Selanjutnya kelompok mempresentasikan hasil kerja mereka di depan kelas dengan car menceritakan kembali cerita anak tersebut dan menerangkan isinya dengan cara menjelaskan gambar-gambar atau foto-foto yang mewakili isi dari wacana cerita anak yang mereka pilih.

\section{- Hubungan Pembelajaran Mendengarkan Cerita Anak dengan Pendidikan Karakter}

Herfanda

(2008:131)

mengungkapkan bahwa "sastra memiliki potensi yang besar untuk membawa masyarakat ke arah perubahan, termasuk perubahan karakter". Selain mengandung keindahan, sastra juga memiliki nilai manfaat bagi pembaca. Segi kemanfaatan muncul karena penciptaan sastra berangkat dari kenyataan sehingga lahirlah suatu paradigma bahwa sastra yang baik menciptakan kembali rasa kehidupan. Penciptaannya yang dilakukan bersamasama dan saling berjalinan seperti terjadi dalam kehidupan kita sendiri.

Akan tetapi, kenyataan yang ada dalam sastra di dalam sastra dihadirkan melalui berbagai tahap proses kreatif. Artinya, bahan-bahan tentang kenyataan 
tersebut dipahami melalui proses penafsiran baru oleh pengarang. Salah satu sastra yang berpotensi besar membawa anak ke arah perubahan adalah cerita anak. Cerita anak mempunyai andil besar untuk mengubah cara pikir, kebiasaan, cita-cita, harapan, dan sikap seorang anak karena di dalam cerita anak terdapat karakter cerita. Applebee (dalam Gunarsa, 2004:70) beragumen bahwa "karakter cerita menjadi bagian dunia nyata anak dan menjadi bagian dari warisan budaya mereka".

Adapun manfaat cerita anak bagi anak adalah berkenaan dengan nilai-nilai yang terkandung di dalamnya agar anak lebih mampu menerjemahkan persoalanpersoalan dalam hidup melalui kebaikan jasmani dan kebaikan rohani mereka. Lebih jauh dari itu cerita anak dalam kaitan dengan pendidikan karakter, yaitu cerita anak sebagai media pembentuk watak moral anak, dengan cerita anak kita bisa mempengaruhi anak untuk memahami, merasakan, dan mengamalkan nilai-nilai yang terkandung di dalamnya.

Pesan-pesan moral baik secara
implisit maupun eksplisit dapat disampaikan melaui cerita anak. Cerita anak dapat pula dijadikan media untuk membentuk karakter anak. Nilai-nilai kejujuran, kebaikan, persahabatan, persaudaraan, kekeluargaan, keikhlasan, ketulusan, kebersaman, dan lain sebagainya yang berhubungan dengan pendidikan karakter, bisa kita terapkan kepada anak melalui cerita anak.

\section{Penutup}

Cerita anak merupakan media yang berpotensi tinggi mengajarkan nilai-nilai kehidupan agar dapat dikembangkan dalam kehidupan nyata mereka. Agar siswa dapat menjadi pribadi yang berbudi, pendidikan karakter perlu ditanamkan melalui proses pembelajaran. Cerita anak perlu diajarkan kepada anak untuk mengembangkan nilainilai dan norma-norma yang berkembang dalam kehidupan bernasyarakat. Melalui cerita anak karakter anak dapat dirubah dan dapat mengamalkan nilai yang ada, oleh sebab itu cerita anak perlu ditanamkan melalui proses pembelajaran. Cerita anak mempunyai andil besar untuk mengubah cara pikir, kebiasaan, cita-cita, harapan, dan sikap seorang anak karena di dalam cerita anak terdapat karakter cerita yang menjadi bagian dunia nyata anak. 


\section{Jurnal Ilmiah Bahasa dan Sastra \\ ISSN : 23557083 \\ Volume 3 Nomor 2 Desember 2016}

\section{Daftar Pustaka}

Gunarsa, Singgih D. 2004. Dari Anak Sanpai Usia Lanjut. Jakarta: BPK Gunung Mulia.

Herfanda, A.Y. 2008. Sastra Sebagai Agen Perubahan Budaya dalam Bahasa dan Budaya dalam Berbagai Perspektif. Yogyakarta: FBS UNY dan Tiara Wacana.

Koesoema, Doni. 2007. Pendidikan Karakter (Strategi Mendidik Anak di Zaman Global). Jakarta: PT. Grasindo.

Latif, Yudi. 2009. Menyemai Karakter Bangsa. Jakarta: PT Kompas Media Nusantara.

Musfiroh, Tadkiroatun. 2003. Bercerita untuk Anak Usia Dini. Jakarta: Departemen Pendidikan Nasional Dirjen Dikti.

Mustakhim, Muhammad Nur.2005. Peranan Cerita dalam Pembentukan Perkembangan Anak TK. Jakarta: Departemen Pendidikan Nasional Dirjen Dikti.

Puryanto, Edi. 2008. Konsumsi Anak dalam Teks Sastra di Sekolah. Makalah dalam Konferensi Internasional Kesusastraan XIX HISKI.

Soedijarto. 2007. Ilmu \& Aplikasi Pendidikan Bagian 4. Jakarta: PT. Grasindo.

Tarigan, Henry Guntur. 1995. Dasar-dasar Psikosastra. Bandung: Angkasa.

Utomo, Erry. 2011. Pedoman Pelaksanaan Pendidikan Karakter. Jakarta: Kementrian Pendidikan Nasional Badan Penelitian dan Pengembangan Pusat Kurikulum dan Perbukuan. 